

\title{
Using multimodal presentation software and peer group discussion in learning English as a second language
}

\author{
Mei-jung Wang \\ National Kaohsiung University of Hospitality and Tourism
}

\begin{abstract}
This paper reports an application of multimedia in a blended learning environment in which students engaged in multimodal presentations and peer group discussion. Students' presentation files were commented upon by their peers on the discussion board and scored by the researcher, based on questions developed by Levy and Kimber (2009) to apply criteria of design, content and cohesion in analysis of multimodal texts. After the discussion phase, students revised their files and answered a questionnaire about their perception of the value of this practice for language learning. Regarding the production of presentation files, most aspects of the title slide and overall slide designs were performed well, except for a lack of dynamic effects and inadequate consideration of the visual perception of the audience. Peer group discussion and the scoring can assist the students in inspiring their creativity and modification of the designs of their presentations. In contrast, other aspects such as language use were not improved, probably due to the limited language proficiency of the students or their unawareness of the need for further improvement. The questionnaire results indicate that students appreciated peer group discussions and understood that they might need increased skills to use the presentation software in a more sophisticated way.
\end{abstract}

\section{Introduction}

The hybrid form of electronic texts composed of semiotic modes such as video, graphics, images and animation, plus written texts, differs from the print-based convention (Lin, 2007). Jewitt (2002) stated that, in a transfer from page to screen, students learn to make sense of representational modes in a range including image, movement, gesture and voice, and suggested that an interaction of students with visual texts demands that "'reading' and the process of learning within school English be regarded as more than a linguistic accomplishment" (p. 171). The potential for multimodal representations to assist language learners, and whether e-generation students having a heightened media literacy might also participate in the instructional process as designers and creators of materials has been debated (Prensky, 2008). Levy and Kimber (2009) suggested that creations by youths using the new techniques be investigated further to understand what is involved in learning and producing multimodal texts.

This study investigated the application of multimedia in a reading course in which students were involved in multimodal presentations and peer group discussions. After reading selected English novels, students explained the characters and plots of those novels with presentation software (Microsoft PowerPoint). Their presentation files were commented upon by their peers on the discussion board and scored by the researcher, 
using questions developed by Levy and Kimber (2009) for applying criteria of design, content and cohesion in analyses of multimodal texts. This paper aims to 1) study how the salient features of multimodal products are illustrated in the designs of the title slide and overall slides; 2) analyse which aspects of the salient features are improved after peer feedback; and 3) reveal how students perceive the value of such a practice for language learning.

\title{
Literature review
}

Literacy is typically described as an ability to read and to write. A new definition of literacy emerged after the recent evolution of information and communication technologies. For instance, Barton, Hamilton and Ivanic (2000) regarded literacy as social practices, "the general cultural ways of utilizing written language which people draw upon in their daily lives" (p. 7). The Centre for Literacy defined literacy as abilities in a complicated set that people apply to understand the dominant symbol systems of a culture, including alphabets, numbers and visual icons:

\begin{abstract}
In a technological society, literacy extends beyond the functional skills of reading, writing, speaking and listening to include multiple literacies such as visual, media and information literacy. These new literacies focus on an individual's capacity to use and make critical judgments about the information they encounter on a daily basis. (The Centre for Literacy, n.d.)
\end{abstract}

The need to redefine literacy in the electronic age entails the development of a metalanguage facilitating meta-textual awareness of image and text relations (Unsworth, 2006). Many scholars (e.g. Duncum, 2004; Jaén, \& Basanta, 2009; Jewitt, 2005a; Mariani, 1997) stressed that communication between human beings generally involves varied modalities and meaning is interpreted through communication in varied modes including music, the spoken voice, sound effects, language, and pictures. Kress and van Leeuwen (1996) proposed that images, like language, realise simultaneously meanings of three kinds: representations of material reality, and the interpersonal interaction of social reality, and semiotic reality. Unsworth (2006) emphasised similarly that images and texts can instantiate and extend each other; critical understanding of the interpretive possibilities of texts must thus take all ideational, interpersonal and compositional perspectives into the making of meaning. He called for an urgent need to proceed beyond logocentric accounts of literacy and literacy pedagogy to make sense of the increasingly integrative use of images with language in texts in electronic and paper media of many and varied types.

With the popularity of information communication technologies (ICTs), many authors worldwide have explored the screen-based literacy practices of young people (Kimber \& Wyatt-Smith, 2009; Luo, 2009; Walsh, 2009; Wheeler \& Wheeler, 2007). Without a doubt, in countries with abundant computers, the predominant means of communication is multimodal for young people in the current generations (Vicent, 2005). Jewitt (2005b) stated that "The particular material and social affordances (Kress \& van Leeuwen, 2001; van Leeuwen, 2005) of new technologies and screen, as opposed to page, have led to the reconfiguration of image and writing on screen in ways that are significant for writing and reading (p. 315)." She further challenged the educational foregrounding of the written word and advocated educational research and practice to look beyond the linguistic level. 
In terms of second language (L2) learning, Chapelle (1997) considered that the facilitation of L2 acquisition depends upon beliefs regarding the types of language use that are expected to be beneficial for L2 development. Current youth, described by some as the e-generation, recognises the importance of computer literacy in future endeavours because the world is primarily connected through the Internet. Many researchers (e.g. Bower, 2011; Conroy, 2010; Lin \& Wu, 2010; Wang, 2010; Ware \& O'Dowd, 2008; Zorko, 2009) have studied the effects of the application of ICTs in facilitating students' L2 learning. Most of the research results confirm the potential benefits of ICTs for students' L2 proficiency. Under these circumstances, traditional print-based criteria of assessment are inappropriate for assessing the production of digitally mediated texts (Wyatt-Smith \& Kimber, 2005) and classroom teachers need specific directions and training to improve the relation between learning and new technologies, to accommodate current literacy practice (Dooly, 2011; Levy \& Kimber, 2009; Wang \& Ip, 2010).

Educators such as Daiute (1992) and Sutherland (1995) have advocated the integration of multiple modes into the standard curriculum. Royce (2006) urged that "literacy pedagogy should account for the burgeoning variety of text forms connected with information and multimedia technologies and the proliferation of communication channels and media supporting and extending cultural and subcultural diversity" (p.9). In modern societies, people need to learn to interpret and to design visual symbols, images and other modes of representation and communication (Kenner, 2004; Thorne \& Payne, 2005). Especially for students who failed to communicate successfully in literacy expression, the multimedia environments provided by ICTs have some potential to help them, so curriculum design in literacy education requires modification if expected text production is to be both multimodal and monomodal (Vicent, 2005).

Levy and Kimber (2009) agreed that a multimodal text is a complicated and multifaceted artifact that learners can adopt to express meaningful connections, but such multimodal texts are problematic in terms of description, evaluation and assessment; they thus adopted some criteria focusing on discrete elements and their interplay to make meaning in a multimodal text for the purpose of comparative analysis across two or more texts. Their work shows that the focus on design, content and cohesion applied to title slides, headings and knowledge representation enabled a comparison between students. They discovered also an acute awareness of the complicated nature of the production of multimodal texts and understood not only the salient features of multimodal texts but also the need for students to have an improved fluency within and across those features to improve the total quality of their production.

\section{Method}

\section{Subjects}

Forty-four freshmen from the Department of Applied English (7 males and 37 females) who participated in this project had enrolled in an English reading course during the period of the project (18 weeks from February to June in 2010). All had taken computer courses during senior high schools and had acquired experience in the use of software (Microsoft PowerPoint) for presentation. 


\section{Instruments}

Of two instruments adopted in this project, one entails the dimensions of product analysis developed by Levy and Kimber (2009) including the criteria of design, content and cohesion. These authors also defined key features required to discuss and to determine the quality of multimodal texts as follows:

- the first slide in the set (title slide);

- the choice and shape or wording in the headings of individual slides throughout the set (headings), and

- the quality of knowledge revealed in each slide and the complete slide set (knowledge representation) (p. 493).

For the present work, all questions in Levy and Kimber (2009) are listed as the scoring rubrics (Tables 1 to 3 ) and with a five-point scale for each item. The first item serves as an example: "Did the author use or manipulate an existing template? Or create her/ his own?" If the group used an existing template appropriately, they were awarded three points, but, if the group used an existing template inappropriately, they were awarded one point. If the group created their own template appropriately, they received five points. In this way, the presentation files of the groups were analysed and compared.

The other instrument is a questionnaire on the perceived value of such a practice to improve language learning. Of eleven items, the first ten items are questions on a fivepoint Likert scale; one open-ended question is included at the end.

\section{Procedures}

The students were taught general reading skills and strategies for reading novels for the first 9 weeks. Meanwhile, the forty-four students (ten groups, four or five persons per group) read four selected English novels. From the tenth week, each group introduced the characters and summarised the plots of the novel with presentation software. Given that each group may read different novels, the students were advised to be informative but concise during the 5-10 minute presentation which was recorded with a web camera. Afterwards, each group's PowerPoint file and the web camera recording of all the members giving an oral presentation with the PowerPoint slides were uploaded to the Web Instruction Platform provided by the university for teachers to upload teaching materials, design online tests, and direct online discussions. The purposes of uploading both the files and the web camera recording are for students to comment on the other groups' PowerPoint files and reflect on their own performance of the presentation.

This study merely examines the visual/verbal texts of the PowerPoint files; students were therefore guided to comment mainly on how well the multimodal texts were produced, focusing on design, content and cohesion applied to title slides, headings and knowledge representation. However, students were free to give comments on the oral presentation because lengths of comments were not regulated. Each student had to submit comments written in English for other groups' presentation on the discussion board. Thus each group received 39 or 40 individual comments. Afterwards, each group summarised all the comments. In addition, the researcher scored the initial PowerPoint files based on the criteria developed by Levy and Kimber (2009) to analyse multimodal texts, and gave the results to each group. Finally, each 
group discussed how to revise the file according to the peer comments and the evaluation scores.

At the end of the course, the researcher scored the revised PowerPoint files and then compared the scores of the initial PowerPoint files and the revised ones. Moreover, students reflected on the activity and answered a questionnaire about their perceived value of such a practice to improve their learning.

\section{Results and discussions}

\section{Results of the presentation files}

By focusing on the design, content and cohesion across the slide set, the researcher examined multimodal texts created by the students. Responses 'strongly agreed' and 'agreed' were consistently summed. The results of the performance of the students for the first part of the criteria, design, appear in Table 1.

Table 1: Results of the design of the presentation files ( $\mathrm{N}=10$ groups)

\begin{tabular}{|c|c|c|c|c|c|c|c|c|c|c|c|c|}
\hline \multirow{2}{*}{\multicolumn{2}{|c|}{ Design }} & \multicolumn{2}{|c|}{5 points } & \multicolumn{2}{|c|}{4 points } & \multicolumn{2}{|c|}{3 points } & \multicolumn{2}{|c|}{2 points } & \multicolumn{2}{|c|}{1 points } & \multirow{2}{*}{$\begin{array}{c}\mathrm{P} \\
\text { value }\end{array}$} \\
\hline & & 1st & 2nd & $1 \mathrm{st}$ & 2nd & $1 \mathrm{st}$ & 2nd & 1st & 2nd & 1 st & 2nd & \\
\hline 1.1. & $\begin{array}{l}\text { Did the author use or manipulate an } \\
\text { existing template? Or create her/ his } \\
\text { own? }\end{array}$ & 20 & 60 & 40 & 10 & 30 & 30 & 0 & 0 & 10 & 0 & .111 \\
\hline 1.2 . & $\begin{array}{l}\text { What effect is created by the size and/ } \\
\text { or choice of image/ color / font style? }\end{array}$ & 10 & 10 & 70 & 70 & 10 & 20 & 10 & 0 & 0 & 0 & .343 \\
\hline 1.3. & $\begin{array}{l}\text { Were dynamic elements used } \\
\text { effectively? }\end{array}$ & 0 & 10 & 40 & 40 & 30 & 40 & 20 & 10 & 10 & 0 & .096 \\
\hline & $\begin{array}{l}\text { Is the font style appropriate for the } \\
\text { topic/treatment? }\end{array}$ & 20 & 20 & 40 & 50 & 30 & 30 & 10 & 0 & 0 & 0 & .758 \\
\hline 1.5 . & $\begin{array}{l}\text { Are color choices appropriate/ } \\
\text { aesthetically pleasing? }\end{array}$ & 20 & 30 & 40 & 30 & 20 & 30 & 20 & 10 & 0 & 0 & .591 \\
\hline 1.6. & $\begin{array}{l}\text { What relevance or effectiveness do any } \\
\text { graphics or symbols in the heading/s } \\
\text { have? }\end{array}$ & 40 & 40 & 40 & 40 & 10 & 20 & 10 & 0 & 0 & 0 & .343 \\
\hline 1.7. & $\begin{array}{l}\text { Does the choice of color/ template/ } \\
\text { graphic contribute to the making of } \\
\text { meaning in the text? }\end{array}$ & 30 & 30 & 20 & 50 & 50 & 20 & 0 & 0 & 0 & 0 & .081 \\
\hline 1.8. & $\begin{array}{l}\text { Do images add impact to the } \\
\text { construction of meaning? }\end{array}$ & 50 & 50 & 30 & 40 & 20 & 10 & 0 & 0 & 0 & 0 & .678 \\
\hline 1.9. & $\begin{array}{l}\text { Does the presentation of information } \\
\text { engage the viewer / reader visually } \\
\text { and/or dynamically? }\end{array}$ & 10 & 10 & 50 & 60 & 20 & 20 & 20 & 10 & 0 & 0 & .343 \\
\hline 1.10 . & $\begin{array}{l}\text { Does the progressive revelation of } \\
\text { information about the topic contribute } \\
\text { to the viewer's engagement with the } \\
\text { information? }\end{array}$ & 40 & 40 & 20 & 50 & 30 & 10 & 10 & 0 & 0 & 0 & .309 \\
\hline
\end{tabular}

Listed under each column of the scores from 5 points to 1 point are the percentages of groups with that score. The presentation files were evaluated twice based on all the factors from 1.1 to 1.10 under the "Design" column. Their first scores are shown under "1st" of each score's column and the revised ones were evaluated as listed below "2nd" under each score's column. A $t$-test was then performed based on the two scores and the calculated values are recorded under the "P value" column in the table. Tables 2-3 follow the same pattern. Concerning the original files, students generally designed 
the slides well except for items 1.3 and 1.7. For example, more than 60 percent of the groups designed the title slide well enough so that these slides showed an appropriate match with the proper colors, fonts, images and sizes (items 1.1, 1.2, 1.4, 1.5, 1.6, 1.8 and 1.10).

An outstanding work by Group A (Figure 1) presented colours in an effective choice (white and pink) and font (Jokerman) for the names of the group and group members, but no group applied animation (Item 1.3) to increase the dynamic elements in a presentation. Some color tones of both background and word content showed no contrast so that the whole page might repel the audience as presented in Figure 2 (Item 1.7). A possible interpretation is that students designed the slides based on their own aesthetic standards; they might be unskillful at productions with the presentation software. Another possibility is that most groups probably focused on completing the task without considering the visual perceptions of the audience.

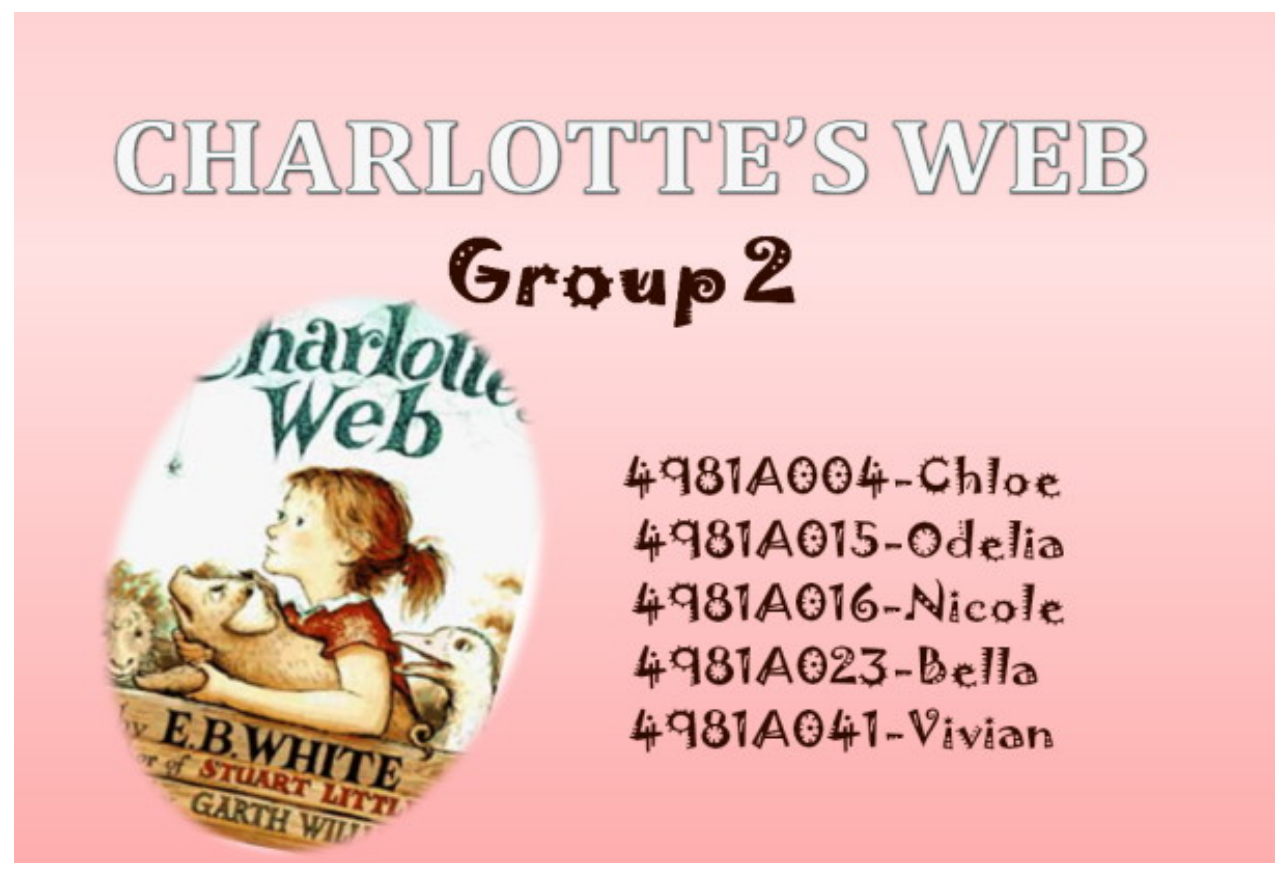

Figure 1: The title slide of Group A

Throughout the peer discussion, the students exchanged opinions and learned consciously from the construction of other presentations. Based on the feedback received, students became increasingly skillful in the manipulation of a slide template in the aspect of design criteria although no significant differences were found as the $p$ values in Table 1 indicate. For instance, the choices of color, template design, image, and font style enabled making a slight improvement (items 1.1, 1.3, and 1.7). The modified versions appeared to be better blended and complementary.

As for the application of a color tone, there was a substantial correlation with the multiliteracy, the multimodal relations between significant processes that are so critical in media texts and the texts of electronic multimedia (as cited in Duncum, 2004). Duncum (2004) stated that the study of visual imagery is concerned with the entire 
context of images, their production and the lived experience of those who view and interpret them. Such evidence has accounted for the improvement because varied perspectives from the peer discussion might have inspired the creativity of students and adjusted their direction in the design of their presentations.

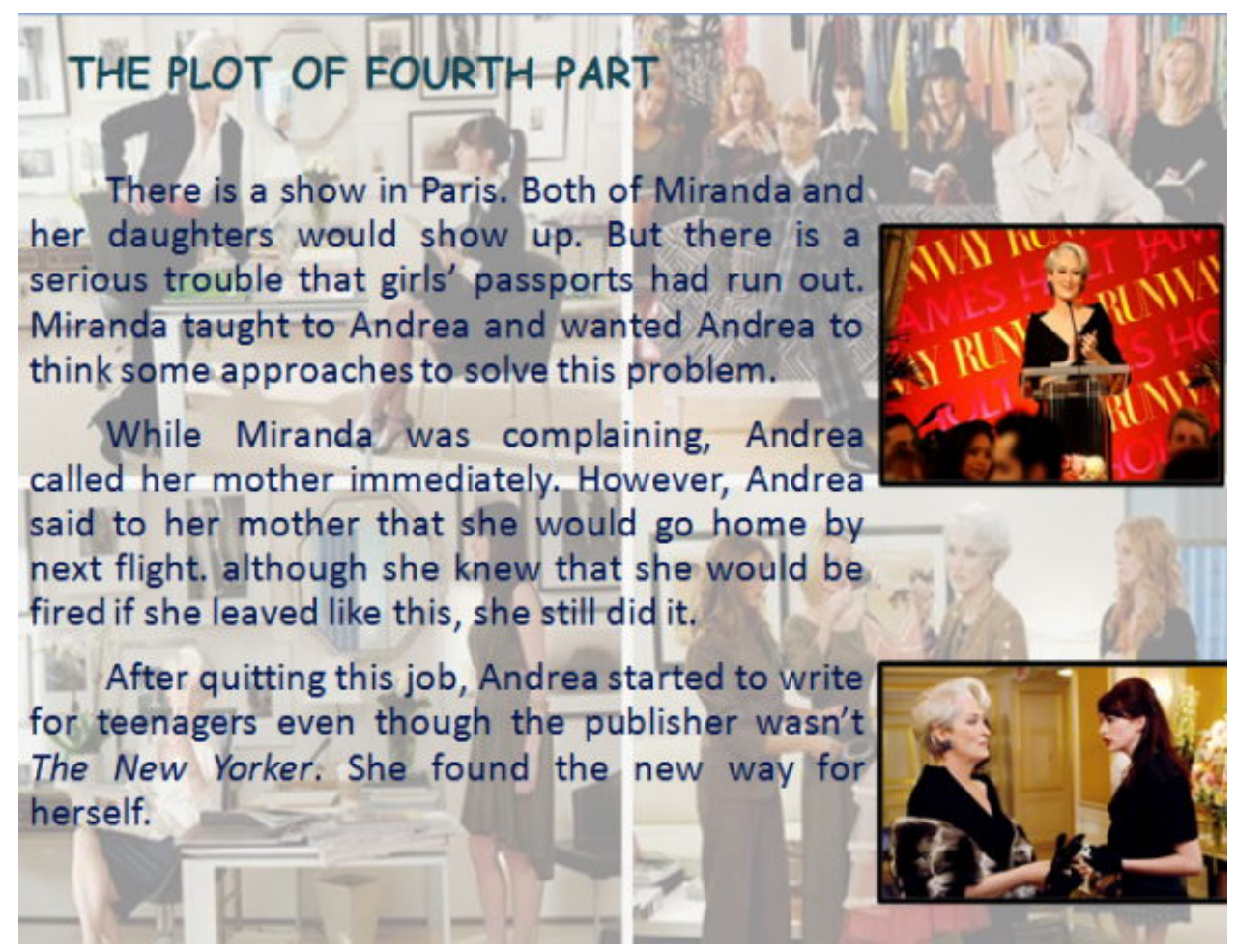

Figure 2: A slide by Group B

For the second part of the criteria, the content, results are presented in Table 2. Concerning the initial files, the results of items 2.1 and 2.2 show that most groups were bound by the novel title and thus failed to create new topics. For instance, most groups presented their titles with a phrase based on the original novel titles, and some groups focused on the concept of the character introduction. These phenomena might result from a concept that the adoption of a novel title influenced the viewer to a particular stance on the topic (Item 2.3).

In terms of content of the headings across the slide set, as the students were asked to introduce the novels, the groups were prevented from producing informational or conceptual or questioning topics (Item 2.4), but most headings were an assembly of the various contents that elaborated multiple points of view of the topic. The most common examples are the character introduction and the plot introduction (Item 2.5). In Group A, for example, the headings "plot", "narrate", "figurative language", "settings", and "trailers" were used across the slide set. These headings constructed various aspects of the novel and engaged the viewers to read the further information because the presentation topic, slide headings and the content are strongly correlated among one another (Item 2.6). 
Table 2: Results of the content of the presentation files ( $\mathrm{N}=10$ groups)

\begin{tabular}{|c|c|c|c|c|c|c|c|c|c|c|c|c|}
\hline \multirow{2}{*}{\multicolumn{2}{|c|}{ Content }} & \multicolumn{2}{|c|}{5 points } & \multicolumn{2}{|c|}{4 points } & \multicolumn{2}{|c|}{3 points } & \multicolumn{2}{|c|}{2 points } & \multicolumn{2}{|c|}{1 points } & \multirow{2}{*}{$\begin{array}{c}\mathrm{P} \\
\text { value }\end{array}$} \\
\hline & & 1st & 2nd & 1st & 2nd & 1st & $2 \mathrm{nd}$ & 1st & 2nd & 1st & 2nd & \\
\hline 2.1. & $\begin{array}{l}\text { Is the title a phrase, statement or } \\
\text { concept? }\end{array}$ & 10 & 0 & 0 & 0 & 80 & 90 & 10 & 10 & 0 & 0 & .343 \\
\hline 2.2. & $\begin{array}{l}\text { Is the title descriptive, informative, or } \\
\text { subjective? }\end{array}$ & 0 & 0 & 0 & 0 & 100 & 100 & 0 & 0 & 0 & 0 & .343 \\
\hline 2.3. & $\begin{array}{l}\text { Does the title position the viewer to a } \\
\text { particular stance on the topic? }\end{array}$ & 40 & 40 & 40 & 50 & 10 & 10 & 0 & 0 & 10 & 0 & .343 \\
\hline 2.4. & $\begin{array}{l}\text { Is the choice of wording } \\
\text { informational, conceptual, } \\
\text { questioning or ...? }\end{array}$ & 0 & 0 & 10 & 20 & 20 & 30 & 70 & 50 & 0 & 0 & .193 \\
\hline 2.5. & $\begin{array}{l}\text { Do the headings help to construct } \\
\text { multiple viewpoints on the topic? }\end{array}$ & 40 & 40 & 10 & 10 & 10 & 30 & 20 & 20 & 20 & 0 & .423 \\
\hline 2.6. & $\begin{array}{l}\text { How do the heading / s relate to the } \\
\text { viewer? Position the viewer to } \\
\text { engage with a particular stance on } \\
\text { the topic? }\end{array}$ & 20 & 20 & 50 & 70 & 10 & 10 & 10 & 0 & 10 & 0 & .213 \\
\hline 2.7. & $\begin{array}{l}\text { Does the content reveal depth/ } \\
\text { breadth of knowledge? }\end{array}$ & 10 & 10 & 20 & 40 & 10 & 10 & 50 & 30 & 10 & 10 & .104 \\
\hline 2.8. & $\begin{array}{l}\text { Does the content reveal the author's } \\
\text { capacity to process / seek multiple } \\
\text { sources / perspectives? }\end{array}$ & 10 & 10 & 10 & 10 & 0 & 30 & 60 & 50 & 20 & 0 & .096 \\
\hline 2.9. & Is the content well-synthesised? & 10 & 10 & 10 & 30 & 40 & 40 & 20 & 10 & 20 & 10 & .052 \\
\hline 2.10. & $\begin{array}{l}\text { Is the content in the author's own } \\
\text { words or copied / pasted from other } \\
\text { sources? }\end{array}$ & 30 & 30 & 10 & 20 & 30 & 30 & 30 & 20 & 0 & 0 & .168 \\
\hline 2.11. & Are sources acknowledged? & 0 & 0 & 0 & 20 & 10 & 10 & 0 & 0 & 90 & 70 & .168 \\
\hline 2.12. & Is language use proficient? & 10 & 0 & 40 & 30 & 30 & 70 & 20 & 0 & 0 & 0 & .758 \\
\hline
\end{tabular}

With regard to the knowledge representation in the content (Items 2.7-2.12), the performance of most groups was less than satisfactory. As the evaluation of Item 2.8 shows, only two groups in ten revealed a capacity to seek multiple perspectives. The content was poorly synthesised because most groups merely copied the words from the novels without clearly presenting diversified elements to compose an acceptable report (Items 2.9-2.10). Worse, only two groups acknowledged the trailer links (e.g. Figure 3) (Item 2.11). Evaluation of whether the language use was proficient was difficult because much language was quoted from the novels (Item 2.12).

About the content across the set of slides for the revised files, the students improved their understanding of the impact of their individual slide theme on the viewers probably because of the enforcement through an exposure to the work of other groups. They might consequently improve their content by collecting various resources and synthesising the gathered resources. As a result, particular aspects related to content have been graded superior based on the statistical analyses including items 2.7, 2.8, 2.9, 2.10 and 2.11. Although the improvement is statistically insignificant, the slight improvement can result from the peer discussion that enhanced understanding, even when no student in a discussion group knew originally the best answer; the latter condition is unnecessary in multimodal evaluation because of the individual differences (Smith, Wood, Adams, Wieman, Knight, Guild \& Su, 2009). 


\section{TRRATLER}

+ It was so popular that It rolled out its movie version. It was a New Year movie in 2007.

+ http://www.youtube.com/watch?v=ORMcpzpmLTU

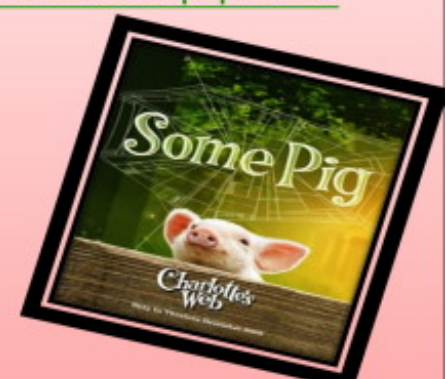

Figure 3: Trailer by Group A

Table 3: Results of the cohesion of the presentation files ( $\mathrm{N}=10$ groups)

\begin{tabular}{|c|c|c|c|c|c|c|c|c|c|c|c|c|}
\hline \multirow{2}{*}{\multicolumn{2}{|c|}{ Cohesion }} & \multicolumn{2}{|c|}{5 points } & \multicolumn{2}{|c|}{4 points } & \multicolumn{2}{|c|}{3 points } & \multicolumn{2}{|c|}{2 points } & \multicolumn{2}{|c|}{1 points } & \multirow{2}{*}{$\begin{array}{c}\mathrm{P} \\
\text { value }\end{array}$} \\
\hline & & 1st & 2nd & 1st & 2nd & 1st & 2nd & 1st & 2nd & 1st & 2nd & \\
\hline & $\begin{array}{l}\text { Do choices in colour, template } \\
\text { design, image and font style } \\
\text { "match" the topic? }\end{array}$ & 30 & 10 & 40 & 80 & 30 & 10 & 0 & 0 & 0 & 0 & .591 \\
\hline 3.2 . & $\begin{array}{l}\text { Do choices in colour, template } \\
\text { design, image and font style } \\
\text { complement / blend / conflict with } \\
\text { each other? }\end{array}$ & 10 & 10 & 0 & 0 & 0 & 20 & 60 & 60 & 30 & 10 & .104 \\
\hline 3.3 . & $\begin{array}{l}\text { Are headings used throughout the } \\
\text { slide set? }\end{array}$ & 70 & 80 & 0 & 20 & 10 & 0 & 0 & 0 & 20 & 0 & .121 \\
\hline 3.4 . & $\begin{array}{l}\text { Are the headings disparate or do } \\
\text { they help to construct a cohesive set } \\
\text { within the parameters of the task? }\end{array}$ & 30 & 40 & 30 & 40 & 10 & 20 & 30 & 0 & 0 & 0 & .168 \\
\hline 3.5 . & $\begin{array}{l}\text { Does the sum total of all nodal } \\
\text { information contribute to a } \\
\text { balanced treatment of the topic? }\end{array}$ & 40 & 30 & 40 & 50 & 10 & 10 & 10 & 10 & 0 & 0 & 1.000 \\
\hline 3.6. & $\begin{array}{l}\text { Does the overall structure of } \\
\text { information respond to all key } \\
\text { elements required by the task? }\end{array}$ & 20 & 10 & 50 & 80 & 30 & 10 & 0 & 0 & 0 & 0 & .591 \\
\hline
\end{tabular}

An indispensible criterion in evaluation of multimodal texts, cohesion, was examined in the last section (Table 3). The result for item 3.2 "Do choices in color, template design, image and font style complement / blend / conflict with each other?" showed that six groups might have struggled slightly in designing color schemes, template, images and font styles. A positive result was reported in item 3.3. Most groups applied the headings throughout a slide set. Based on items 3.4 and 3.5, the figures did not imply astonishing results of evaluation. Students were generally able to construct cohesive nodal information through headings. It is encouraging that no group failed to complete the task by responding to most key elements required by the tasks according to the positive results shown in item 3.6. 
Regarding the revised files, the cohesion in the choices of colour, template design, image, and font style became similarly slightly improved (items 3.2 and 3.3). The modified versions appeared to be better blended and more complementary from the point of view as shown in the following slide by Group B (Figures $2 \& 4$ ) as an example. A salient progression is the design of the knowledge representation across the set of slides. The color tones of both background and fonts belong to Mazarin blue. To make the slide content more readable and more pleasant, Group B adjusted the background to be brighter and the fonts to be darker and bigger to exhibit the contrast. The arrangements of the pictures and columns made the layout more dynamic. The peer discussion inspired students to adjust the design of their presentation, and the cohesion likewise improved.

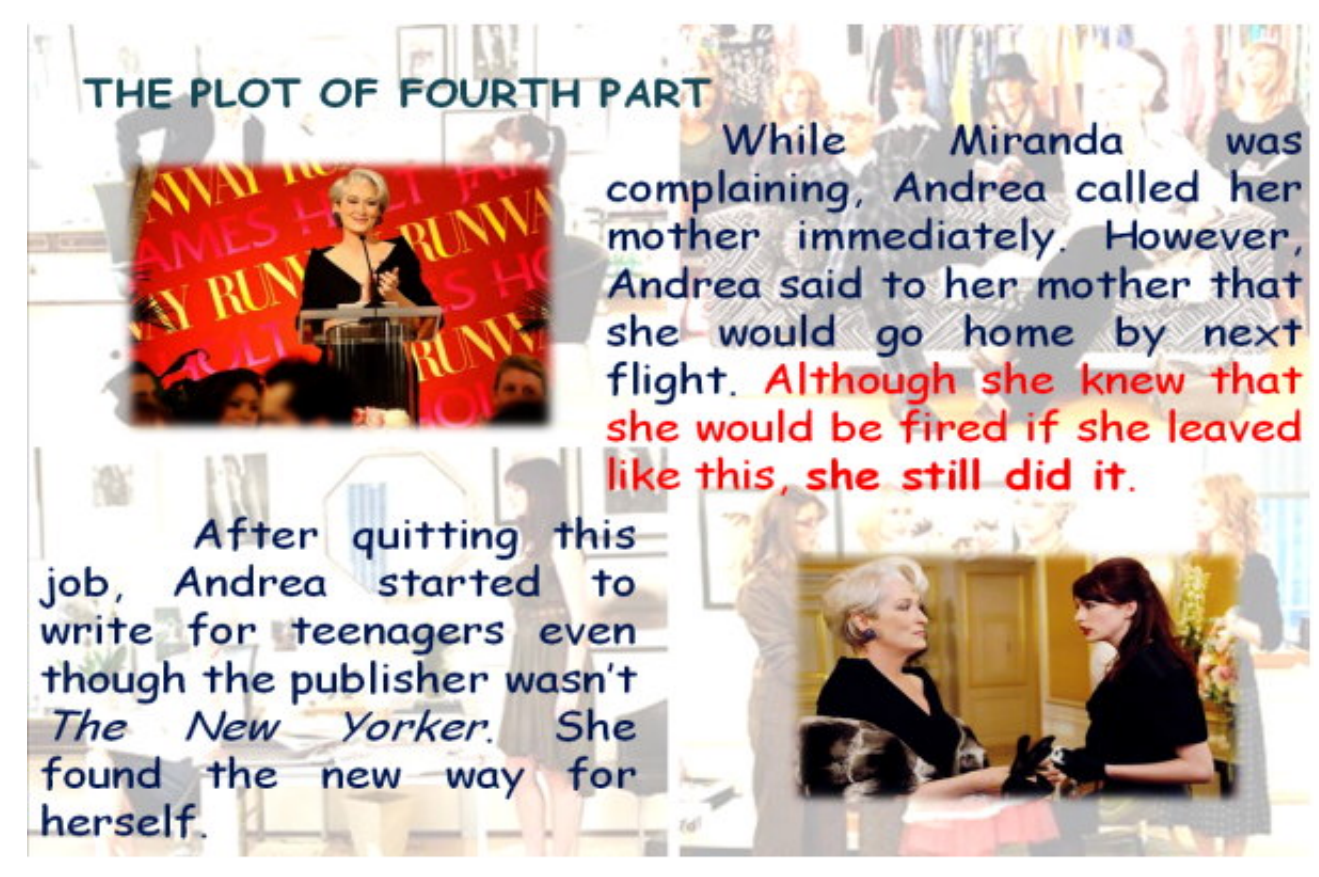

Figure 4: Group B revised version

After examining the slight progress made by the participants, the focus is now shifted to the criteria of multimodal texts that showed no improvement. Likely because of a lack of motivation and a limited ability in English, the students made no attempt to improve their use of the language; grammatical errors persisted. The language used in the content, including the heading, failed in the attempt to engage the viewers (e.g. Figures 5 and 6). Apart from the limited language ability, creativity was possibly restrained by the thematic establishment, the novel character introduction. An innovative manner of expressing language could scarcely be found under such circumstances. 
- Mr.Penderwick

Four Penderwick sisters' father whotakes care of them

after their mother's death.

Guide them into the correct way without hit or scolding.

- Rosalind

12 yearsold, getting to 13

Takes care of Batty

Play a mother's role in the family

Very gentle and fell in love with Cagney

o Jane

An imaginative,ten-year-old girl

Like to write a book about "Sabrina Starr Rescues something

Like to hang out with her sister Skye

- Churchie

A nice woman whotakes care Mrs. Tifton and her son,

Jeffery

The house keeper and is willing to help Penderwicks and

Jeffery when they lived in Arundel Cottage.

Figure 5: First version by Group C

\section{《Four sisters》}

\section{Roserlind}

12 yearsold, getting to 13

Takes care of Batty

Play a mother's role in the family

Verygentle and fell in love with Cagney

\section{- Detne}

An imaginative, ten-year-old girl

Like to write a book about "Sabrina Starr Rescues something

Like to hang out with her sister Skye

Figure 6: Revised version by Group C

\section{Results of the questionnaire}

This section explores the students' perceptions of the activity based on the results of the questionnaire. Responses to the five-point Likert type were compiled by percentage and responses to the open-ended question were classified according to themes; the tabulated results are presented in Table 4. 
Table 4: Results of the self perception of learning ( $\mathrm{N}=44$ students)

\begin{tabular}{|c|c|c|c|c|c|c|}
\hline & \multicolumn{5}{|c|}{ Percentage } \\
\hline & & $\begin{array}{c}\text { Strongly } \\
\text { agree }\end{array}$ & Agree & $\begin{array}{c}\text { Neu- } \\
\text { tral }\end{array}$ & $\begin{array}{l}\text { Dis- } \\
\text { agree }\end{array}$ & $\begin{array}{l}\text { Strongly } \\
\text { disagree }\end{array}$ \\
\hline 1. & $\begin{array}{l}\text { I surfed the Internet for related information } \\
\text { because of this activity. }\end{array}$ & 65.8 & 29.3 & 4.9 & 0 & 0 \\
\hline 2. & $\begin{array}{l}\text { I surfed the Internet for related pictures because } \\
\text { of this activity. }\end{array}$ & 65.9 & 34.1 & 0 & 0 & 0 \\
\hline 3. & $\begin{array}{l}\text { I surfed the Internet for related films because of } \\
\text { this activity. }\end{array}$ & 60.9 & 34.2 & 4.9 & 0 & 0 \\
\hline 4. & I had no difficulty making a PowerPoint. & 9.7 & 48.8 & 36.6 & 4.9 & 0 \\
\hline 5. & $\begin{array}{l}\text { Making a PowerPoint helped me to better } \\
\text { understand the contents of the novel. }\end{array}$ & 26.8 & 63.4 & 9.8 & 0 & 0 \\
\hline 6. & $\begin{array}{l}\text { The responses of my classmates on the message } \\
\text { board are useful to improve my PowerPoint. }\end{array}$ & 29.2 & 48.8 & 14.6 & 4.9 & 2.4 \\
\hline 7. & $\begin{array}{l}\text { The scores for the PowerPoint are useful for the } \\
\text { improvement of the revision. }\end{array}$ & 17.1 & 51.2 & 29.3 & 2.4 & 0 \\
\hline 8. & $\begin{array}{l}\text { Group work is useful for improving the contents } \\
\text { of PowerPoint. }\end{array}$ & 41.5 & 46.3 & 9.8 & 2.4 & 0 \\
\hline 9. & $\begin{array}{l}\text { The presentations of other groups helped me to } \\
\text { understand the contents of other novels. }\end{array}$ & 14.6 & 65.9 & 14.6 & 4.9 & 0 \\
\hline 10. & Overall, I like this activity. & 9.7 & 51.2 & 31.7 & 4.9 & 2.4 \\
\hline 11. & $\begin{array}{l}\text { Overall, this activity can help to improve my } \\
\text { English reading and writing skills. }\end{array}$ & 7.3 & 61.0 & 21.9 & 7.3 & 2.4 \\
\hline
\end{tabular}

Several conclusions might be drawn from Table 3. First, almost all students used the Internet to seek information, pictures and related films. This confirms the findings of the previous studies (e.g. Kimber \& Wyatt-Smith, 2009; Vicent, 2005) that the egeneration evidently has no hesitation in utilising the Internet to seek information that it desires. Second, about PowerPoint file construction (items 4-6), although only 58.5 percent of the students expressed no difficulty in making such a presentation, $90.2 \%$ of the students thought that such a practice helped them understand better the content of the novel.

Third, the feedback received from the peers and the instructor was helpful to improve the presentation. $78.0 \%$ of the students agreed that they benefited from the feedback and suggestions of their classmates, and $68.3 \%$ of the students agreed that the grades of the presentation files were helpful for the revision. Students responded positively to the group work. $87.8 \%$ of the students agreed that group work is useful to improve the content of the presentation and $80.5 \%$ agreed that the presentations of other groups were helpful in understanding the contents of other novels. $60.9 \%$ of the students expressed a liking for this activity and $68.3 \%$ of the students agreed that this activity could help them to improve their skills in reading and writing English.

The responses by students to the open-ended question "What do I learn from this activity?" are classifiable as follows. Most students $(\mathrm{N}=25)$ expressed that they learned to correct their mistakes and to improve the content of their presentations according to the feedback from their peers. Many students $(\mathrm{N}=16)$ thought that they would have benefited from further training in construction of a presentation to polish it. For example, they wrote too many words on the slide such that the main point became 
obscured. In addition, the arrangement of words and photos was improvable. As Unsworth (2006) mentioned, the complementary relation of language and image signifies that, under certain circumstances, images can extend text, and vice versa. To strike a balance between words and pictures so that the audience could comprehend the information via multimedia presentation depends on the decision of users.

Students recognised the deficiencies of their oral presentation as well; they $(\mathrm{N}=20)$ remarked that the control of volume, speed and intonation was adjustable to improve their oral presentation. In contrast, they were happy when other students remarked that their oral presentation was satisfying and interesting. The students acknowledged the power of cooperation; through communication with group members, they benefited from team work. They also claimed that they could draw the main ideas of a new novel from the presentation of another group. Most students completed reading their first English novel in the process of doing this activity, and improved their ideas of the novel through construction of the presentation.

\section{Conclusions}

The findings are summarised as follows. About the multimodal files constructed by the students, most aspects of the title slide and overall slide design were performed well, apart from a lack of dynamic effects. The selection of coloring and toning of the presentation indicated that the students took insufficient consideration of the perception of the audience. About the content, the topics were presented in a limited way, as the participants might have restricted themselves to the novel title and genre, and dared not try more creative ideas. Similar constraints applied to the content introduction, which comprised excessive material directly copied. Most students failed to acknowledge their sources. Students might have struggled slightly to design color schemes, template, images and font styles, but students were generally able to construct cohesive nodal information through headings and responded to most key elements required by the tasks.

The peer discussion enabled the students to offer opinions and to learn from each other. Improvements, although not substantial, were discernible in coloring, design and content. Peer discussion can clearly help students enhance their knowledge and mutual understanding because peer discussion provided varied perspectives that helped inspire students' creativity and modify their direction in the design of their presentations. In contrast, other aspects such as language use were not improved; this condition might reflect the limited language proficiency of the students or their lack of an awareness of the need for further improvement.

The questionnaire results indicate that students were able to utilise Internet resources to gather information. Working in groups helped improve the content of presentations, and their construction helped them to understand the novel, which was the first English novel that most students had read. They appreciated peer feedback that improved their work and understood that they might need increased skills to manipulate the software in refining their slide set. They discovered that adjustments to speed, intonation and volume can be helpful when they made their oral presentations, and were happy that others commented on their presentations as interesting.

In total, these results indicate that creativity, language ability and source acknowledgment are the aspects requiring improvement. As mentioned before, few 
creative headings and layouts were presented, even after the peer discussion, because of the constraints of the tasks, but a development of creativity is neither unnecessary nor untrainable for students. Writing in English can likewise be improved by second verification and frequent practice. Acknowledgment of sources is a significant concept that students in Taiwan universities need to reinforce; students must be instructed to acknowledge the sources that they gather from either the Internet or elsewhere to indicate credits to the authors.

In addition, students need increased training in creative thinking and critical thinking to release them from merely copying the titles and texts from the novels that they have read. Specific training in literature terminology and figurative speech might be helpful for them to present the gist of the novel in a more sophisticated way. Workshops on the presentation software and the operation of other office software might aid students to take advantage of effects to animate the text, pictures and charts in sparing and judicious ways to improve the focus on important points (Daffron, 2008). Training in presentation skills and etiquette is necessary for them to enhance the information that they seek to communicate. Not only students but also teachers must improve their fluency within and across those features because students are exposed to the presentation files of teachers that they might regard as the standard.

The adoption of such detailed items from criteria of Levy and Kimber (2009) helped teachers to examine thoroughly the key multimodal features of the products, but difficulty arises in answering every question because the production of multimodal text is complicated, as stated by Levy and Kimber (2009) in their conclusion. To be specific, both the questions of multiple choice and the other questions made evaluation difficult. For example, item 1.1, "Did the author use or manipulate an existing template? Or create her or his own?", comprises three questions. Another ambiguous example is item 2.12, "Is language use proficient?" Whenever a student uses a copy and paste method, language proficiency cannot be evaluated satisfactorily. The question in 3.1, 'Do choices in color, template design, image and font style "match" the topic?' might be subjective for evaluation.

Three suggestions are made for future studies. First, teachers from varied subjects can adapt the criteria to discover the advantages and disadvantages of applying them to evaluate and to compare presentations of students. Teachers can revise some criteria according to their teaching contexts, and provide these criteria to students in advance to direct their attention to improving specific aspects of the multimodal product. Second, the results of this study calls for attention to pedagogical innovations for language teachers. That is, the nature of training that might improve the multimodal products of students is worth exploring. As shown in this article, peer feedback can assist the revision of the products only in particular aspects. The kinds of training needed and the methods for achieving the effects are worthy of study to yield increased thoughts for teachers to promote the literacy of students in our modern society. Finally, future studies can explore the possibilities of cross-modality transfer, such as the transfer between the use of synchronous computer mediated communication (SCMC) and oral language production as indicated by Thorne and Payne (2005). The nature of cross-modality transfer is an area needing more investigation so that L2 teachers can utilise appropriate ICT tools to efficiently improve students' foreign language proficiency. 


\section{Acknowledgments}

This paper is supported by National Science Council in Taiwan (NSC 99-2410-H-328007-). The author would like to thank the students who participated in this project. Thanks also go to the reviewers' insightful comments and the Production Editor's valuable feedback.

\section{References}

Barton, D., Hamilton, M. \& Ivanic, R. (2000). Situated literacies: Reading and writing in context. London: Routledge.

Bower, J. (2011). Negotiation of meaning and corrective feedback in Japanese/English eTandem. Language Learning \& Technology, 15(1), 41-71. http: / / llt.msu.edu / issues / february2011/ bowerkawaguchi.pdf

Chapelle, C. (1997). CALL in the year 2000: Still in search of research paradigms. Language Learning E Technology, 1(1), 19-43. http://1lt.msu.edu/vol1num1/chapelle/default.html

The Centre for Literacy (n.d.). What is literacy? http: / / www.centreforliteracy.qc.ca/about/literacy

Conroy, M. A. (2010). Internet tools for language learning: University students taking control of their writing. Australasian Journal of Educational Technology, 26(6), 861-882. http: / / www.ascilite.org.au/ajet/ajet26/ conroy.html

Daffron, S. C. (2008). Adding transition and animation effects in PowerPoint. [viewed 31 Oct 2010, verified 30 Oct 2011] http: / / www.computorcompanion.com/LPMArticle.asp?ID=254

Daiute, C. (1992). Multimedia composing: Extending the resources of the kindergarten to writers across the grades. Language Arts, 69, 250-260.

Duncum, P. (2004). Visual culture isn't just visual: Multiliteracy, multimodality and meaning. Studies in Art Education, 45(3), 252-264.

Jaén, M. \& Basanta, C. (2009). Developing conversational competence through language awareness and multimodality: The use of DVDs. ReCALL, 21(3), 283-301. http: / / dx.doi.org/10.1017/S0958344009990036

Jewitt, C. (2002). The move from page to screen: The multimodal reshaping of school English. Journal of Visual Communication, 1(2), 171-196. http: / / dx.doi.org/10.1177/147035720200100203; http: / / eprints.ioe.ac.uk/856/

Jewitt, C. (2003). Reshaping literacy and learning: A multimodal framework for technology mediated learning. Unpublished doctoral dissertation, Institute of Education, London University.

Jewitt, C. (2005a). Technology, literacy, learning. London: Routledge Falmer.

Jewitt, C. (2005b). Multimodality, "reading", and "writing" for the 21st century. Discourse: Studies in the Cultural Politics of Education, 26(3), 315-331. http: / / dx.doi.org/10.1080/01596300500200011

Kenner, C. (2004). Becoming biliterate: Young children learning different writing systems. Stoke on Trent: Trentham Books.

Kimber, K. \& Wyatt-Smith, C. (2009). Rethinking quality assessment for 21st century learning: How students use and create knowledge online. Paper presented at IAEA 2009 Assessment for a Creative World. [verified 30 Aug 2011] http: / / griffith.academia.edu/KayKimber/ Papers/351522/Rethinking_Quality_Assessment_for_21_St_Century_Learning_How_Stude nts_Use_and_Create_Knowledge_Online 
Kress, G. \& van Leeuwen, T. (1996). Reading images: The grammar of visual design. London: Routledge.

Kress, G. \& van Leeuwen, T. (2001). Multimodal discourse: The modes and media of contemporary communication. London: Arnold.

Levy, M. \& Kimber, K. (2009). Developing an approach for comparing students' multimodal text creations: A case study. Australasian Journal of Educational Technology, 25(4), 489-508. http: / / www.ascilite.org.au/ajet/ajet25/levy.html

Lin, J. M.-C. \& Wu, Y.-J. (2010). Netbooks in sixth-grade English language classrooms. Australasian Journal of Educational Technology, 26(7), 1062-1074. http:/ / www.ascilite.org.au/ajet/ajet26/lin.html

Lin, Y. Y. (2007). An exploratory study of English multimedia writing: Implementing Weblogs in a college composition class. Unpublished Masters thesis, National Tsing-hua University.

Luo, L. (2009). Web 2.0 integration in information literacy instruction: An overview. Journal of Academic Librarianship, 36(1), 32-40. http:/ / dx.doi.org/10.1016/j.acalib.2009.11.004

Mariani, J. J. (1997). Spoken language processing and multimodal communication: A view from Europe. In NSF Workshop on Human-Centered Systems: Information, Interactivity and Intelligence (HCS). Arlington, VA. http:/ / www.ifp.uiuc.edu/nsfhcs/talks/mariani.html

Prensky, M. (2008). Students as designers and creators of educational computer games: Who else? British Journal of Educational Technology, 39(6), 1004-1019. http: / / dx.doi.org/10.1111/j.1467-8535.2008.00823_2.x

Royce, T. D. (2006). Multimodal communicative competence in second language contexts. In Royce, T. D. \& Bowcher, W. L. (Eds.), New directions in the analysis of multimodal discourse (pp. 361-390). New Jersey: Lawrence Erlbaum Associates, Inc.

Smith, M. K., Wood,W. B., Adams, W. K., Wieman, C., Knight, J. K., Guild, N. \& Su, T. T. (2009). Why peer discussion improves student performance on in-class concept questions. Science, 323, 122-124. http:/ / dx.doi.org/10.1126/ science.1165919

Sutherland, R. (1995). Mediating mathematical action. In R. Sutherland \& J. Mason (Eds.), Exploiting mental imagery with computers in mathematics education (pp. 71-79). Berlin: Springer.

Thorne, S. L. \& Payne, J. S. (2005). Internet-mediated text and multi-modal expression in foreign language education. CALPER Working Paper Series, No. 5. The Pennsylvania State University, Center for Advanced Language Proficiency, Education and Research. http: / / calper.la.psu.edu/publication.php?page=wps5

Unsworth, L. (2006). Towards a metalanguage for multiliteracies education: Describing the meaning making resources of language-image interaction. English Teaching: Practice and Critique, 5(1), 55-76. http: / / www.eric.ed.gov:80 / ERICWebPortal/ contentdelivery/ servlet/ ERICServlet?accno=EJ843820

van Leeuwen, T. (2005). Introducing social semiotics. London: Routledge.

Vicent, J. (2005). Multimodal literacies in the school curriculum: An urgent matter of equity. Preprints of papers included in the Conference Book: Recent Research Developments in Learning Technologies. http: / / citeseerx.ist.psu.edu/viewdoc/ download?doi=10.1.1.138.7714 \&rep $=$ rep $1 \&$ type $=$ pdf

Walsh, C. S. (2009). The multi-modal redesign of school texts. Journal of Research in Reading, 32(1), 126-136. http: / / dx.doi.org/10.1111/j.1467-9817.2008.01385.x 
Ware, P. D. \& O'Dowd, R. (2008). Peer feedback on language form in telecollaboration. Language Learning and Technology, 12(1), 43-63. http: / / llt.msu.edu/vol12num1/pdf/wareodowd.pdf

Wang, M. J. (2010). Online collaboration and offline interaction between students using asynchronous tools in blended learning. Australasian Journal of Educational Technology, 26(6), 830-846. http: / / www.ascilite.org.au / ajet/ ajet26/ wang.html

Wang, M. J. \& Ip, K. I. (2010). Tasks and challenges faced by teachers in handling an online project. Asian EFL Journal, 12(4), 143-158. http: / / www.asian-efljournal.com/December_2010_mjw.php

Wheeler, S. \& Wheeler, D. (2007). Evaluating wiki as a tool to promote quality academic writing skills. Paper presented at the Conference ICL2007, 26-28 September, Villach, Austria. http: / / telearn.noe-kaleidoscope.org/warehouse/158_Final_Paper_(001680v1).pdf

Wyatt-Smith, C. \& Kimber, K. (2005). Valuing and evaluating student-generated online multimodal texts: rethinking what counts. English in Education, 39, 22-43. http: / / dx.doi.org/10.1111/j.1754-8845.2005.tb00615.x

Zorko, V. (2009). Factors affecting the way students collaborate in a wiki for English language learning. Australasian Journal of Educational Technology, 25(5), 645-665. http: / / www.ascilite.org.au/ajet/ajet25/zorko.html

Author: Dr Mei-jung Wang, Associate Professor Department of Applied English

National Kaohsiung University of Hospitality and Tourism

I, Sung-Ho Road, Hsiaokang District, Kaohsiung, Taiwan, 812

Email: sebrinajoy@yahoo.com.tw

Please cite as: Wang, M.-J. (2011). Using multimodal presentation software and peer group discussion in learning English as a second language. Australasian Journal of Educational Technology, 27(6), 907-923. http: / / www.ascilite.org.au/ ajet/ ajet27/ wangmj.html 